\title{
Resistance of Neisseria gonorrhoeae Grown in vivo to Ingestion and Digestion by Phagocytes of Human Blood
}

\author{
By K. WITT \\ Microbiological Research Establishment, Porton, Wiltshire SP4 oJG \\ D. R. VEALE, HAZEL FINCH, C. W. PENN, D. SEN AND H. SMITH \\ Department of Microbiology, University of Birmingham, P.O. Box 363, \\ Birmingham BI 5 2TT
}

(Received 25 February 1976)

\begin{abstract}
SUMMAR Y
Attempts to study quantitatively the phagocytosis of gonococci from urethral pus failed because of the small numbers of organisms and technical difficulties. However, gonococci from chambers implanted subcutaneously in guinea pigs, which were similar to gonococci from urethral pus in their resistance to killing by human serum, were obtained in sufficient quantities for comparison in phagocytosis tests with the in vitro grown strain from which they were derived.

Microscopic and viable counts of gonococci in phagocytes showed that in vivo grown organisms (strain BSV) were readily phagocytosed by human polymorphonuclear phagocytes. There was little difference between BSV organisms and the in vitro grown organisms (strain BS) in resistance to ingestion. There was, however, a marked difference in the intracellular survival of strains BSV and BS during the first hour of phagocytosis. Whereas BSV organisms survived well, many BS organisms were killed. Subsequently, strain BSV and the survivors of the strain BS inoculum responded similarly to the intracellular bactericidins. These results were supported by electron microscopy of infected phagocytes.

Resistance of gonococci in vivo to ingestion and digestion by human phagocytes seem to be important facets of the pathogenesis of gonorrhoea.
\end{abstract}

\section{INTRODUCTION}

Strongly staining gonococci are seen both extracellularly and intracellularly in urethral pus from patients with gonorrhoea. The presence of extracellular organisms suggests overloading of phagocytic capacity and indicates that some gonococci in vivo may resist phagocytosis. However, the presence of intracellular organisms shows that phagocytosis occurs and, further, that gonococci may resist the intracellular bactericidins. Thus resistance to ingestion and digestion by polymorphonuclear phagocytes (PMN phagocytes), the predominant cell type in urethral pus, would be important in acute infection; and survival inside the fewer mononuclear phagocytes (MN phagocytes) could be important in chronic infection.

Pilated, small-colony gonococcal types resembling the virulent Kellogg types 1 and 2 (Kellogg et al., 1963, I968) seem to be less easily ingested by phagocytes than non-pilated, large-colony types resembling the avirulent Kellogg types 3 and 4 (Punsalang \& Sawyer, I973; Ofek, Beachey \& Bisno, 1974; Dilworth, Hendley \& Mandell, I975; Gibbs \& Roberts, 1975; Witt, Veale \& Smith, 1976), with the exception of the non-pilated large-colony type described by Swanson et al. (1974) which is of unknown virulence for man. In some reports a 
clear distinction has been made between intracellular and cell-attached gonococci, e.g. by electron microscopy (Witt et al., I976), by phase-contrast microscopy (Gibbs \& Roberts, 1975) and by fluorescent antibody staining (Dilworth et al., 1975). Thus, resistance to ingestion appears to be correlated with the virulence for man of the Kellogg types, but whether or not pili are responsible for the resistance is still a matter of dispute (Swanson et al., 1974).

With regard to resistance to intracellular killing, appreciable numbers of a pilated, small-colony-forming strain of gonococcus (BS) resembling Kellogg type 2 survived and multiplied within human buffy-coat phagocytes (predominantly PMN phagocytes) over I $5 \mathrm{~h}$ and also survived for at least $6 \mathrm{~h}$ in the few MN phagocytes that could be separated from the buffy coat (Veale et al., 1976). A non-pilated, large-colony-forming strain (AL) resembling Kellogg type 4 survived at a much lower level than the BS strain and was destroyed in Io to I 2 h (Veale et al., 1976). Thus, with strains $\mathrm{BS}$ and $\mathrm{AL}$, resistance to digestion could be correlated with infectivity for guinea-pig chambers (Veale et al., 1975) and, by analogy with the Kellogg types, with potential virulence for man. These results are in accord with electron microscopic observations of human urethral pus (Novotny, Short \& Walker, 1975) that intracellular survival and growth occurs in gonorrhoea. However, the above phagocytosis tests were conducted with gonococci grown in vitro and there is increasing evidence that gonococci grown in vivo are different.

Urethral pus gonococci were more resistant to killing by human serum and complement than the same strains grown in vitro (Ward, Watt \& Glynn, 1970). They also had different walls and were less pilated (Novotny et al., 1975). When our BS strain was passaged three times through plastic chambers implanted subcutaneously into guinea pigs after the method of Arko (Arko, 1972; Veale et al., 1975), its infectivity was increased about roo-fold and it formed markedly smaller colonies. It appeared to produce some different antigens in gel-diffusion and, like urethral pus organisms, it became resistant to killing by human serum (Penn et al., 1975, 1976). These observations prompted us to examine the phagocytosis of gonococci grown in vivo.

\section{METHODS}

Gonococcal strains. Strain BS (pilated, small-colony-forming, $\mathrm{MID}_{\mathbf{5 0}}$ for subcutaneously implanted guinea-pig chambers about $10^{3}$, resembling Kellogg type 2) was derived, stored and cultured as described by Veale et al. (1975).

Strain BS grown in vivo (BSv) was prepared as follows. Strain BS organisms were passaged three times through guinea-pig chambers (Veale et al., 1975; Penn et al., 1975); the chamber contents of the third passage were diluted about I to 40 with I \% (w/v) Proteose Peptone (Difco) and $8 \%(\mathrm{v} / \mathrm{v})$ glycerol in water and stored in $0.5 \mathrm{ml}$ aliquots in liquid nitrogen. For an individual phagocytosis test, a thawed aliquot (containing about $\mathrm{I} \times 10^{4}$ organisms) was diluted with $0.5 \mathrm{ml}$ saline and $0.25 \mathrm{ml}$ amounts were introduced into 3 to 4 guinea-pig chambers (Veale et al., 1975), from each of which $0.25 \mathrm{ml}$ of fluid had been removed for $24 \mathrm{~h}$ sterility tests. After $24 \mathrm{~h}, 2 \mathrm{ml}$ of fluid (about ${ }^{16}$ gonococci $/ \mathrm{ml}$ ) were removed from each chamber and the bulked sample $(6$ to $8 \mathrm{ml}$ ) was centrifuged at $380 \mathrm{~g}$ for Io min to remove blood cells. Fluid $(0.25 \mathrm{ml})$ was withdrawn from each of $\mathrm{I} 2$ fresh guinea-pig chambers for $24 \mathrm{~h}$ sterility tests and replaced by the infected exudate $(0.25 \mathrm{ml})$. After another $24 \mathrm{~h}$, infected exudate (about $2 \mathrm{ml} /$ chamber) was collected from chambers which had been sterile when inoculated. The bulked exudate ( 20 to $25 \mathrm{ml}$ ) was centrifuged at $380 \mathrm{~g}$ for $\mathrm{Io}$ min to remove blood cells, and the supernatants were centrifuged at $2600 \mathrm{~g}$ for $\mathrm{I} \mathrm{h}$. The deposited organisms were resuspended in Parker medium $199(\mathrm{BDH})$ containing $10 \%(\mathrm{v} / \mathrm{v})$ heated 
human serum (Witt et al., 1976). Helber chamber counts of gonococci could not be made because of other particles. Hence, the total number of gonococci per ml was estimated by comparing the number of stained gonococci in 40 fields of a standard smear $\left(\mathrm{I} \mathrm{cm}^{2}\right)$ made from one loopful of suspension (Smith et al., I96I) with the corresponding number in fields of a similar smear from a suspension of BS organisms of known concentration. The suspension was then diluted for the phagocytosis tests. Subsequent viable counts on suspensions of BSV organisms were 50 to $140 \%$ of the total counts.

Culture media. These were described by Veale et al. (1975) and Witt et al. (1976).

Human phagocytes. Populations consisting predominantly of PMN phagocytes (about $80 \%$ ) were obtained as described by Witt et al. (1976).

Phagocytosis tests. Modified forms of the tests for assessing the relative abilities of gonococcal strains to resist ingestion and digestion by phagocytes described by Witt et al. (I976) and Veale et al. (1976) were used. The ratio of gonococci to PMN phagocytes was reduced from between 20:I and I00: I to approximately $I: I$ and particular attention was paid to total and viable counts of gonococci found in phagocyte deposits that attach to glass during the first $\mathrm{I} h$ ingestion period. The essential steps were as follows. A suspension of gonococci $\left(0.5 \mathrm{ml}\right.$; about $\left.2 \times 10^{6} / \mathrm{ml}\right)$ and a suspension of PMN phagocytes $\left(0.5 \mathrm{ml}\right.$; about $\left.2 \times 10^{6} / \mathrm{ml}\right)$ in Parker medium 199 containing $10 \%(\mathrm{v} / \mathrm{v})$ isologous heated $\left(56^{\circ} \mathrm{C} ; 30 \mathrm{~min}\right)$ human serum were mixed in Leighton tubes. Control tubes contained gonococci but no PMN phagocytes. The tubes were gassed $\left(5 \% \mathrm{CO}_{2} / 95 \%\right.$ air) and incubated at $37^{\circ} \mathrm{C}$ to allow phagocytosis of organisms to occur, and for the cells to become attached to the glass. One $h$ after mixing (all experiments), and also at 15 and 30 min after mixing in some experiments, tubes were taken and the viable organisms in the supernatants and in the deposits attached to the glass were counted as described by Veale et al. (1976). From the total number of phagocytes attached to the glass, the proportion of them containing gonococci, and the average number of gonococci ingested by them (Witt et al., 1976), the total gonococci visibly associated with phagocytes per slide was estimated. After $I \mathrm{~h}$ ingestion, the supernatant was removed from the remaining tubes and the cell deposits were washed (Earle's saline; $3 \times 5 \mathrm{ml}$ ) before a bactericidal medium $(0.5 \mathrm{ml} /$ tube $)$ containing fresh human serum $(50 \%, \mathrm{v} / \mathrm{v})$ and penicillin $\left(0.4 \mu \mathrm{g} \mathrm{ml}^{-1}\right)$ in Parker medium 199 was added. The tubes were incubated for up to $6 \mathrm{~h}$ for assessment of intracellular survival by viable counts of gonococci in the phagocyte deposits attached to the glass. Incubation was not continued as strain BS was known to survive and multiply during $15 \mathrm{~h}$ under similar conditions (Veale et al., 1976). The controls for the phagocytosis test and its interpretation were as described by Witt et al. (1976).

Electron microscopy. Possible differences between strains BS and BSV in their resistance to destruction within human phagocytes were investigated. We are indebted to $\mathrm{Mr}$ B. Dowsett of the Microbiological Research Establishment, Porton, Wiltshire, for taking electron micrographs of ultra-thin sections of the infected (BS and BSV) PMN phagocyte deposits after $\mathrm{I} \mathrm{h}$ ingestion in the standard phagocytosis test described above. Cells containing gonococci were fixed [I \% $(\mathrm{w} / \mathrm{v})$ osmium tetroxide; $4{ }^{\circ} \mathrm{C}$; overnight], embedded in agar, dehydrated in ethanol, embedded in Epon resin, sectioned using a Reichert omu2 ultramicrotome, stained with uranyl acetate $[0.2 \%(\mathrm{w} / \mathrm{v}) ; 30 \mathrm{~min}]$ and lead citrate $[0.04 \mathrm{w} / \mathrm{v})$; I min] and examined under a Philips EM 300 electron microscope (accelerating voltage $60 \mathrm{kV}$ ). Many fields were examined and gonococci associated with phagocytes (I60 for strain BS and 299 for strain BSV) were classified as follows:

I. Intracellular disintegrated gonococci. These included an intact membrane with less than $10 \%$ of the cytoplasm staining, and pieces of membrane with or without attached cytoplasm inside phagosomes (Fig. I $a$ ). These gonococci were undoubtedly dead. 

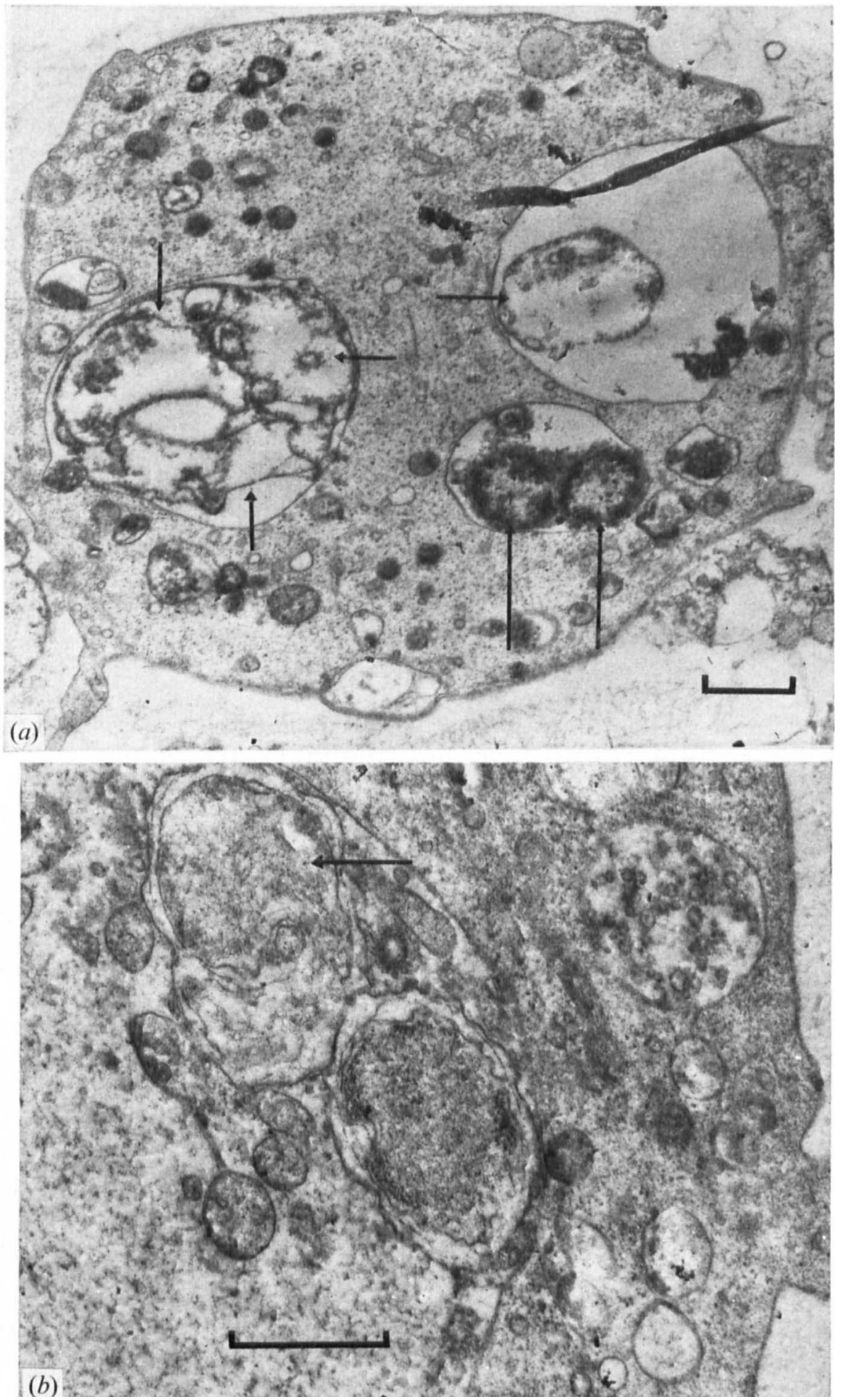

Fig. I. Electron micrographs of sections of PMN phagocytes in deposits attached to glass $\mathrm{I} h$ after mixing with gonococci. (a) Disintegrated gonococci (short arrows) and healthy looking, whole gonococci (long arrows). The latter show a well-defined wall and stained cytoplasm occupying the whole of the bacterial sections. (b) Two, less healthy looking gonococci with paler cytoplasm receding from less well defined walls; at least one of these gonococci was probably dead at the time of sampling (arrow). 
2. Intracellular whole gonococci. The appearance of these organisms varied between two extremes: from those with a complete layered membrane and the whole area of the cytoplasm well stained (Fig. I $a$ ) to others in which, although the majority of cytoplasm was stained, there was shrinkage from the edges near the wall or incompletely stained areas in the centre, and sometimes the membrane was crinkly and less completely layered (Fig. $\mathrm{I} b$ ). Some of the less healthy looking whole gonococci were probably dead at the time of sampling but they had not disintegrated.

3. Extracellular attached gonococci.

The relative proportions of organisms in categories $I$ and 2 indicated the degree of destruction of strains BSV and BS. The proportion of organisms in category 3 indicated the degree of extracellular adherence of the strains.

\section{RESULTS}

Attempts to compare gonococci from urethral pus with strain $\mathrm{BS}$ in phagocytosis tests

Urethral pus could be collected from male patients but only in 0.1 to $0.2 \mathrm{ml}$ amounts containing $10^{4}$ to $10^{6}$ organisms. The test for comparing the ingestion of strains by obtaining phagocytic indices from visual counts (Witt et al., 1976) was modified by using a chamber holding one tenth of the volume and reducing the numbers of strain BS organisms to those in the pus samples. However, in six tests the numbers of gonococci were so few that only I to $2 \%$ of the phagocytes became infected and quantitative work was impossible because counts in experimental tubes were not significantly above background counts of stainable particles in uninfected phagocytes. Two types of tests were used to follow intracellular behaviour. First, gonococci from frozen and thawed pus were mixed with either fresh buffycoat phagocytes (mainly PMN phagocytes) or buffy-coat phagocytes incubated for $24 \mathrm{~h}$ on Leighton tubes (mainly MN phagocytes) in modified versions of the tests described in Methods using lower numbers of pus and strain BS organisms. After I h phagocytosis only a few viable gonococci (about 200 per tube) were detected in the phagocyte deposits attached to the glass even before adding the human serum and penicillin and these disappeared after $\mathrm{I}$ to $2 \mathrm{~h}$ incubation. In the second test, fresh urethral pus was diluted with medium containing fresh human serum and penicillin and incubated in Leighton tubes: PMN phagocytes (some with associated gonococci) settled on the glass surface and viable counts were made at intervals. This test also failed to detect intracellular survival for more than 2 to $3 \mathrm{~h}$ because so few organisms were present initially in the phagocyte deposits and because extracellular pus-grown organisms were more resistant to the killing action of the penicillin/ fresh serum medium than BS organisms grown in vitro. Thus, the concentration of penicillin was either too small (about $0.4 \mu \mathrm{g} \mathrm{ml}^{-1}$ ) to kill all the extracellular organisms so that viable counts on phagocyte deposits did not necesserily indicate intracellular gonococci, or it was large enough ( 2 to $4 \mu \mathrm{g} \mathrm{m}^{-1}$ ) to penetrate the phagocytes and kill intracellular gonoccci (Veale et al., 1976). The results were similar to those reported by Ward, Glynn \& Watt (I972) for incubation of pus with a medium containing penicillin at $\mathrm{I} \mu \mathrm{g} \mathrm{ml}^{-1}$.

\section{Microscopic and viable counts of gonococcal strains BS and BSV in the phagocyte} deposits attached to the glass during phagocytosis by human PMN phagocytes

Figure 2 shows the viable counts and estimates of the total numbers visually associated with the PMN phagocytes for the two strains during the first $2.5 \mathrm{~h}$ of a typical experiment By electron microscopy, the majority of the cell-associated gonococci were intracellular (Table 3; see also Witt et al., 1976). The light microscopic counts indicated that strain BSV 


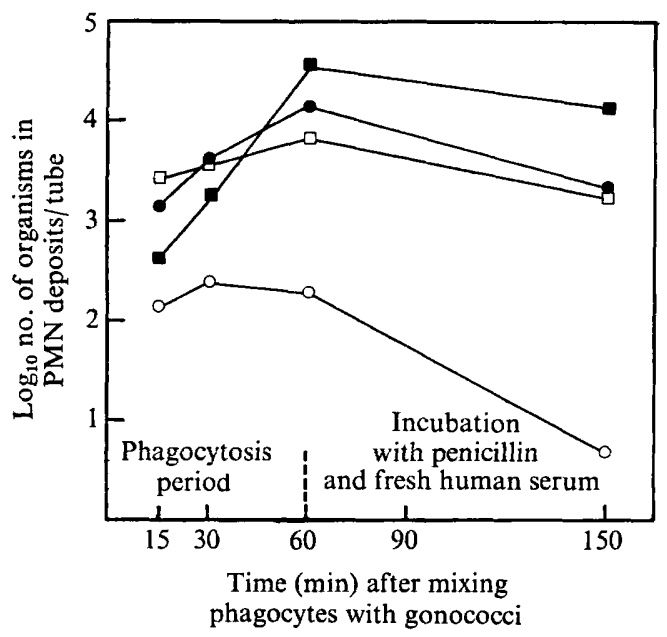

Fig. 2. Viable counts $(\bigcirc, \odot)$ and light microscopic counts $(\square, \mathbf{\square})$ of strain $\mathrm{BS}(\bigcirc, \square)$ and strain BSV $(\boldsymbol{O}, \mathbf{E})$ gonococci in PMN phagocyte deposits attached to glass during the first hour of ingestion by human PMN phagocytes and $1.5 \mathrm{~h}$ after incubation with penicillin $\left(0.4 \mu \mathrm{g} \mathrm{ml}^{-1}\right)$ and fresh human serum. Light microscopic counts were estimated from the total numbers of PMN phagocytes in the deposits, the proportion infected and the average number of gonococci in the infected PMN phagocytes. Inocula before phagocytosis were $6.8 \times 10^{5} \mathrm{BS}$ organisms and $9 \cdot 0 \times 10^{5} \mathrm{BSV}$ organisms.

might be less easily phagocytosed than strain BS at the beginning of the ingestion period but appreciable ingestion of strain BSV took place in $\mathrm{I} h$ in this and other experiments (Table $\mathrm{I}$ ). The striking difference between the two strains was in the relation between the microscopic and viable counts duing the first hour of phagocytosis (Fig. 2). For strain Bs, the viable counts were markedly below the corresponding microscopic counts, indicating that many of the intracellular BS organisms were dead. In contrast, the numbers of viable BSV organisms were similar to the numbers visibly associated with the PMN phagocytes indicating that strain BSV was not killed within the PMN phagocytes as rapidly as was strain BS. Furthermore, the viable count at $\mathrm{I} h$ was markedly greater than that at 30 min for strain BSV but not for strain BS. Results similar to those shown in Fig. 2 were obtained in other experiments (Table I). Because of ingestion of gonococci, the viable counts in the supernatants from experimental tubes after $\mathrm{I} h$ were consistently less than those in the control tubes for both strain BSV and strain BS, although the control counts for strain BSV showed a two to threefold increase over the inoculum whereas those for strain BS showed a reduction to 40 to $80 \%$ of the inoculum. When the supernatants containing strains BS or BSV from experimental tubes after $\mathrm{I} h$ phagocytosis were incubated for a further $\mathrm{I} h$ after removal from the phagocyte deposit, there was an increase not a decrease in viable counts, indicating that bactericidins had not been liberated from the PMN phagocytes.

\section{Intracellular survival of strains BS and BSV when PMN phagocytes were incubated} with a bactericidal mixture of penicillin $\left(0.4 \mu \mathrm{g} \mathrm{ml}^{-1}\right)$ and fresh human serum

Although the numbers of strain BSV surviving in the PMN phagocyte deposits after i $h$ ingestion were higher than those of strain BS from a similar inoculum (Fig. 2; Table 2), the two strains behaved similarly during subsequent incubation of the PMN phagocytes with the bactericidal mixture of penicillin and fresh human serum (Table 2). The numbers of viable strain BSV in the PMN phagocyte deposits remained higher than those of strain BS 
Table I. Viable and microscopic counts of strain BS (grown in vitro) and strain BSV (grown in vivo) gonococci in PMN phagocyte deposits attached to glass during the first hour of ingestion by human PMN phagocytes

Counts of gonococci in PMN phagocyte deposits are expressed per $10^{4}$ of the original viable inoculum. Microscopic counts were estimated from counts of the total number of PMN phagocytes deposited in Leighton tubes, the proportion of PMN phagocytes infected and the average number of gonococci in the infected PMN phagocytes (see Witt et al., 1976).

\begin{tabular}{|c|c|c|c|c|c|}
\hline \multirow[b]{2}{*}{$\begin{array}{r}\text { Blood } \\
\text { sample }\end{array}$} & \multirow[b]{2}{*}{$\begin{array}{c}\text { Inoculum; } \\
10^{-6} \times \text { viable count }\end{array}$} & \multirow[b]{2}{*}{$\begin{array}{l}\text { Ingestion } \\
\text { time (min) }\end{array}$} & \multicolumn{3}{|c|}{ Counts of gonococci } \\
\hline & & & Viable & Microscopic & $\frac{\text { Viable }}{\text { Microscopic }}$ \\
\hline KG & BS; 0.68 & $\begin{array}{l}15 \\
30 \\
60\end{array}$ & $\begin{array}{l}2 \\
3 \\
3\end{array}$ & $\begin{array}{l}36 \\
54 \\
96\end{array}$ & $\begin{array}{l}0.06 \\
0.06 \\
0.03\end{array}$ \\
\hline & BSV; 0.90 & $\begin{array}{l}15 \\
30 \\
60\end{array}$ & $\begin{array}{r}\mathrm{I} 4 \\
44 \\
\mathrm{I} 50\end{array}$ & $\begin{array}{r}4 \\
31 \\
410\end{array}$ & $\begin{array}{l}3 \cdot 5 \\
1 \cdot 3 \\
0 \cdot 37\end{array}$ \\
\hline $\mathrm{CW}$ & BS; 0.40 & $\begin{array}{l}15 \\
30 \\
60\end{array}$ & $\begin{array}{l}5 \\
8 \\
8\end{array}$ & $\begin{array}{r}35 \\
\text { IIO } \\
340\end{array}$ & $\begin{array}{l}0.14 \\
0.07 \\
0.02\end{array}$ \\
\hline & BSV; 0.60 & $\begin{array}{l}15 \\
30 \\
60\end{array}$ & $\begin{array}{r}10 \\
150 \\
590\end{array}$ & $\begin{array}{r}42 \\
180 \\
870\end{array}$ & $\begin{array}{l}0.24 \\
0.83 \\
0.68\end{array}$ \\
\hline KG & BS; $\mathbf{I} \cdot 6$ & $\begin{array}{l}15 \\
30 \\
60\end{array}$ & $\begin{array}{l}2 \\
2 \\
3\end{array}$ & $\begin{array}{r}28 \\
810 \\
720\end{array}$ & $\begin{array}{l}0.07 \\
0.002 \\
0.004\end{array}$ \\
\hline & BSV; I'5 & $\begin{array}{l}15 \\
30 \\
60\end{array}$ & $\begin{array}{r}\text { I I } \\
22 \\
170\end{array}$ & $\begin{array}{c}0.4^{*} \\
24 \\
310\end{array}$ & $\begin{array}{l}(28) \\
0.92 \\
0.55\end{array}$ \\
\hline $\mathrm{CW}$ & $\begin{array}{c}\text { BS; } 1.6 \\
\text { BSV; } 0.45\end{array}$ & $\begin{array}{l}60 \\
60\end{array}$ & $\begin{array}{r}I \\
740\end{array}$ & $\begin{array}{l}260 \\
930\end{array}$ & $\begin{array}{l}0.004 \\
0.79\end{array}$ \\
\hline $\mathrm{CW}$ & $\begin{array}{r}\text { BS; } 0.70 \\
\text { BSV; } 0.60\end{array}$ & $\begin{array}{l}60 \\
60\end{array}$ & $\begin{array}{r}6 \\
I 100\end{array}$ & $\begin{array}{r}82 \\
750\end{array}$ & $\begin{array}{l}0.07 \\
I \cdot 5\end{array}$ \\
\hline $\mathrm{CW}$ & BS; $1 \cdot 0$ & 60 & $\begin{array}{r}2 \\
740\end{array}$ & $\begin{array}{r}93 \\
700\end{array}$ & 0.02 \\
\hline
\end{tabular}

but there was an initial reduction in numbers of both strains, usually followed by an increase a pattern already observed for strain Bs (Veale et al., 1976). The extent of the decrease and increase was similar for both strains. Strain BSV was more resistant than strain BS to fresh human serum alone (Penn et al., 1975) and in the supernatants strain BSV seemed to be more resistant than strain Bs to the bactericidal mixture containing penicillin (Table 2). In most cases, however, the supernatant counts at 2 to $4 \mathrm{~h}$ were so much lower than the deposit counts that the latter could only represent intracellular organisms (see Veale et al., 1976).

Electron microscopy of strains BS and BSV in sections of infected PMN phagocyte deposits

Observations on sections of infected PMN phagocyte deposits I $h$ after phagocytosis of strains BS and BSV are summarized in Table 3. The results support those already described. Of strain BSV organisms, $36 \%$ had not disintegrated after the $\mathrm{I} h$ phagocytosis compared 
Table 2. Recovery of strain BS (grown in vitro) and strain BSV (grown in vivo) gonococci after ingestion by human PMN phagocytes and incubation with a medium containing penicillin and fresh human serum

Gonococci and PMN phagocytes were mixed in the ratio of about $1: 1$ in Leighton tubes. After I h phagocytosis, $10^{4}$ to $10^{5}$ cells (about $80 \%$ PMN phagocytes) were attached to the glass and 50 to $80 \%$ of these remained on the glass after 4 to $6 \mathrm{~h}$. Viable counts of gonococci in the phagocyte deposit, and in the corresponding supernatant (figures in parentheses), were made after the initial ingestion and at intervals after incubation with a bactericidal medium containing fresh human serum and penicillin $\left(0.4 \mu \mathrm{g} \mathrm{ml}^{-1}\right)$. Results are expressed as the number of gonococci per tube: each value is the average of duplicate determinations. Note that these are not progressive counts on the same infected phagocyte population.

\begin{tabular}{|c|c|c|c|c|c|c|c|}
\hline \multirow{2}{*}{$\begin{array}{l}\text { Expt; blood } \\
\text { sample }\end{array}$} & \multirow{2}{*}{$\begin{array}{l}\text { Inoculum; } \\
10^{-6} \times \\
\text { viable count }\end{array}$} & \multirow{2}{*}{$\begin{array}{c}\text { Viable } \\
\text { gonococci* } \\
\text { after } \\
\text { ingestion }\end{array}$} & \multicolumn{5}{|c|}{ Viable gonococci $\uparrow$ after incubation for: } \\
\hline & & & I h & $\mathrm{I} \cdot 5 \mathrm{~h}$ & $2 \mathrm{~h}$ & $4 \mathrm{~h}$ & $6 \mathrm{~h}$ \\
\hline $\mathrm{I} ; \mathrm{KG}$ & $\begin{array}{r}\text { BS; } 0.68 \\
\text { BSV; } 0.90\end{array}$ & $\begin{array}{r}200 \\
13800\end{array}$ & - & $\begin{array}{c}5(<5) \\
2275(520)\end{array}$ & - & - & - \\
\hline $2 ; \mathrm{CW}$ & $\begin{array}{r}\text { BS; } 0.40 \\
\text { BSV; } 0.60\end{array}$ & $\begin{array}{r}300 \\
35625\end{array}$ & - & - & $\begin{array}{r}5(<5) \\
953(250)\end{array}$ & $\begin{array}{c}904(\mathrm{I} 4) \\
2328(\mathrm{I} 20)\end{array}$ & - \\
\hline $3 ; \mathrm{KG}$ & $\begin{array}{r}\text { BS; I.6 } \\
\text { BSV; I } 5\end{array}$ & $\begin{array}{r}456 \\
25750\end{array}$ & - & - & $\begin{array}{l}314(30) \\
1050(8)\end{array}$ & $\begin{array}{l}2313(15) \\
4812(410)\end{array}$ & - \\
\hline $4 ; \mathrm{CW}$ & $\begin{array}{c}\text { BS; } 1 \cdot 6 \\
\text { BSV; } 0.45\end{array}$ & $\begin{array}{r}125 \\
33125\end{array}$ & - & - & $\begin{array}{c}33(14) \\
825(130)\end{array}$ & $\begin{array}{c}138(4) \\
1263(40)\end{array}$ & $\begin{array}{r}5(<5) \\
750(<5)\end{array}$ \\
\hline $5 ; \mathrm{CW}$ & $\begin{array}{c}\text { BS; } 3.5 \\
\text { BS; } 0.70 \\
\text { BSV; } 0.60\end{array}$ & $\begin{array}{r}6000 \\
450 \\
65500\end{array}$ & - & - & $\begin{array}{r}16(<5) \\
<5(<5) \\
220(<5)\end{array}$ & $\begin{array}{r}\mathrm{IO}(<5) \\
<5(<5) \\
30(<5)\end{array}$ & $\begin{array}{r}30(<5 \\
<5(<5 \\
880(<5\end{array}$ \\
\hline $6 ; \mathrm{cW}$ & $\begin{array}{c}\text { BS; I } \cdot 0 \\
\text { BSV; } 0.44\end{array}$ & $\begin{array}{r}175 \\
32750\end{array}$ & $\begin{array}{l}<5(<5) \\
925(128)\end{array}$ & - & $\begin{array}{r}5(<5) \\
88(<5)\end{array}$ & $\begin{array}{l}20(<5) \\
80(<5)\end{array}$ & - \\
\hline
\end{tabular}

* Electron microscopy indicated that most of these organisms were intracellular.

$\dagger$ Supernatants and deposits in control tubes (no PMN phagocytes) were sterile ( $<5$ viable gonococci)

Table 3. Gonococci in electron microscope sections of PMN phagocytes in deposits attached to glass I $h$ after mixing with strain BS or strain BSV

\begin{tabular}{|c|c|c|c|c|}
\hline Strain & $\begin{array}{l}\text { No. of infected } \\
\text { PMN phagocytes } \\
\text { examined }\end{array}$ & $\begin{array}{l}\text { Total no. of } \\
\text { gonococci }\end{array}$ & $\overbrace{\text { Disintegrated } * \text { Whole* }}^{\text {Intracellular gonococci }}$ & $\begin{array}{l}\text { Attached } \\
\text { gonococci }\end{array}$ \\
\hline BSV & II & 299 & I88 & 4 \\
\hline BS & 97 & 160 & I39 & 0 \\
\hline
\end{tabular}

with $13 \%$ of BS organisms. Viable counts indicated that many of the whole organisms were alive. Counts of gonococci in the electron micrographs showed that almost all the cellassociated bacteria in the phagocyte deposits were intracellular (Table 3; see Witt et al., I976).

\section{DISCUSSION}

Despite much effort it proved impossible to conduct satisfactory phagocytosis experiments with gonococci from urethral pus. Therefore, the organisms from guinea-pig chambers were used because they were obtained in larger quantity.

Some gonococci are ingested in vivo by human PMN phagocytes, as was evident from smears of urethral pus, and the gonococci from guinea-pig chambers were ingested to some 
extent by human PMN phagocytes in the tests in vitro (Fig. 2; Table I). Any difference between strains BSV and BS in their resistance to phagocytosis was not marked. Although the microscopic counts of cell-associated gonococci in the early stages of phagocytosis indicated less ingestion of strain BSV than strain BS (Fig. 2), this was not consistent (expt. 2, Table 2).

Strain Bsv resisted intracellular killing by PMN phagocytes during I h phagocytosis more than did strain BS (Fig. I; Table I). This could also be seen from electron microscopy of the infected phagocyte deposits $\mathrm{I} h$ after phagocytosis (Table 3 ). There was a greater proportion of whole gonococci in the sections of the Bsv-infected phagocytes than in those infected with BS. After the first hour of phagocytosis, the subsequent intracellular behaviour of strains BSv and BS was similar (Fig. I; Table 2). The absolute numbers of strain BSV within the PMN phagocytes were greater than those of strain Bs because of the greater resistance of BSv to killing during the first hour. When the infected PMN phagocytes were incubated with the mixture of human serum and penicillin, the counts for both strains first decreased and then increased. This had previously been observed with strain BS in experiments where the ratio of gonococci to PMN phagocytes was higher and where there were more intracellular organisms in the phagocyte deposits before incubating with penicillin (Veale et al., 1976). In the first hour of phagocytosis many BS organisms were ingested and destroyed leaving a residual population with a resistance to intracellular bactericidins similar to that of the gonococci grown in vivo.

On the assumption that the behaviour of gonococci grown in vivo in guinea-pig chambers is similar to that in urethral pus, the results reported here, coupled with previous work by ourselves and others (see Introduction), emphasize that both extracellular and intracellular gonococci are present in urethral pus and scrapings. In the natural disease, virulent gonococci partially resist ingestion by human phagocytes. Some, however, are ingested and a proportion of these survive and multiply intracellularly. Thus, resistance to ingestion and digestion are important facets of the pathogenesis of gonococci. The next step is to identify the aggressins involved.

\section{REFERENCES}

ARKo, R. J. (1972). Neisseria gonorrhoeae: experimental infection in laboratory animals. Science, New York I77, $1200-1201$.

Dilworth, J. A., Hendley, J. O. \& Mandell, G. L. (1975). Attachment and ingestion of gonococci by human neutrophils. Infection and Immunity II, 512-516.

GibBS, D. L. \& RoBERTS, R. B. (1975). The interaction in vitro between human polymorphonuclear leukocytes and Neisseria gonorrhoeae cultivated in the chick embryo. Journal of Experimental Medicine 141, I55-171.

Kellogg, D. S., JR, Peacock, W. L., JR, Deacon, W. E., Brown, L. \& Pirkle, C. I. (I963). Neisseria gonorrhoeae. I. Virulence genetically linked to clonal variation. Journal of Bacteriology 85, I274-1 279.

Kellogg, D. S., JR, Cohen, I. R., Norins, L. C., Schroeter, A. L. \& Reising, G. (1968). Neisseria gonorrhoeae. II. Colonial variation and pathogenicity during 35 months in vitro. Journal of Bacteriology 96, 596-605.

Novotny, P., Short, J. A. \& WALKer, P. D. (I975). An electron-microscope study of naturally occurring and cultured cells of Neisseria gonorrhoeae. Journal of Medical Microbiology 8, 4I3-427.

OFEK, I., BEACHEY, E. H. \& BISNO, A. L. (1974). Resistance of Neisseria gonorrhoeae to phagocytosis: relationship to colonial morphology and surface pili. Journal of Infectious Diseases r29, 310-315.

Penn, C. W., Veale, D. R., Sen, D., WitT K. \& SMITH, H. (1975). Altered pathogenic, morphological and antigenic properties of Neisseria gonorrhoeae adapted to growth in guinea pig subcutaneous chambers. Proceedings of the Society for General Microbiology 3, 57.

Penn, C. W., Sen, D., Veale, D. R., Witt, K., Parsons, N. J. \& Smith, H. (1976). Morphological, biological and antigenic properties of Neisseria gonorrhoeae adapted to growth in guinea pig subcutaneous chambers. Journal of General Microbiology (in the Press).

Punsalang, A. P., JR \& SAWYER, W. D. (1973). Role of pili in the virulence of Neisseria gonorrhoeae. Infection and Immunity 8, 255-263. 
Smith, H., Keppie, J., Pearce, J. H., Fuller, R. \& Williams, A. E. (1961). The chemical basis of the virulence of Brucella abortus. I. Isolation of Br. abortus from bovine foetal tissue. British Journal of Experimental Pathology 42, 63 I-637.

Swanson, J., Sparks, E., Zeligs, B., Siam, M. A. \& Parrott, C. (I974). Studies on gonococcus infection. V. Observations on in vitro interactions of gonococci and human neutrophils. Infection and Immunity I0, 633-644.

Veale, D. R., Smith, H., Witt, K. \& Marshall, R. B. (1975). Differential ability of colonial types of Neisseria gonorrhoeae to produce infection and an inflammatory response in subcutaneous perforated plastic chambers in guinea pigs and rabbits. Journal of Medical Microbiology 8, 325-335.

Veale, D. R., Finch, H., Smith, H. \& WITT, K. (1976). Penetration of penicillin into human phagocytes containing Neisseria gonorrhoeae: intracellular survival and growth at optimum concentrations of antibiotic. Journal for General Microbiology 95, 353-363.

WARD, M. E., WATT, P. J. \& GlYNN, A. A. (I970). Gonococci in urethral exudates possess a virulence factor lost on subculture. Nature, London 227, 382-383.

WARD, M. E., GLYNN, A. A. \& WATT, P. J. (I972). The fate of gonococci in polymorphonuclear leukocytes: an electron microscopic study of the natural disease. British Journal of Experimental Pathology 53, 289-294.

WitT, K., Veale, D. R. \& SMITH, H. (1976). Resistance to ingestion and digestion of Neisseria gonorrhoeae by phagocytes of human buffy coat. Journal of Medical Microbiology 9, I-I 2. 